\title{
Characterization and Gestational Regulation of Corticotropin-releasing Hormone Messenger RNA in Human Placenta
}

\author{
D. M. Frim, "* R. L. Emanuel," B. G. Robinson, “ C. M. Smas," G. K. Adler, " and J. A. Majzoub* \\ *Neuroendocrine Genetics Laboratory, Howard Hughes Medical Institute, Endocrine-Hypertension Division, Department of Medicine, \\ Brigham and Women's Hospital, Harvard Medical School, Boston, Massachusetts 02115; and \$Program in Neuroscience, \\ Department of Neurobiology, Harvard Medical School, Boston, Massachusetts 02115
}

\begin{abstract}
Corticotropin-releasing hormone (CRH), a hypothalamic neuropeptide involved in the regulation of ACTH secretion, has been detected by RIA in extracts of human placenta. We wished to determine whether this immunoreactive substance is a product of CRH gene expression in the placenta. We have found authentic human CRH (hCRH) mRNA in human placental tissue that is similar in size to hypothalamic CRH mRNA. Furthermore, the transcriptional initiation site for placental hCRH mRNA is identical to that previously predicted for hypothalamic hCRH mRNA, 23-26 nucleotides downstream from a canonical promoter element. Placental hCRH mRNA increases more than 20-fold in the 5 wk preceding parturition, in parallel with a rise in placental hCRH peptide content. These data strongly suggest that the hCRH gene is expressed in the placenta and that this expression changes dramatically during gestation.
\end{abstract}

\section{Introduction}

Corticotropin-releasing hormone $(\mathrm{CRH})^{1}$ is a 41 -amino acid neuropeptide synthesized in the paraventricular nucleus of the hypothalamus and released into the hypophyseal-portal system in response to stress (1). It has a major role in the regulation of the hypothalamic-pituitary-adrenal (HPA) axis via its stimulation of proopiomelanocortin gene expression (2) and ACTH release (1) in the anterior pituitary. The expression of hypothalamic CRH is negatively regulated by glucocorticoid hormones $(3,4)$.

A substance detected by antisera to human CRH (hCRH) has been found in extracts of human placenta (5), and in maternal (6-9) and fetal (7-9) plasma. This material is indistinguishable from native hCRH, both in its apparent size $(6,7,9)$ and biological properties $(5,9)$. These studies suggest, but do not definitively demonstrate, that hCRH is synthesized in

Address all correspondence to Dr. J. A. Majzoub, Brigham and Women's Hospital, Department of Medicine, Neuroendocrine Genetics Laboratory, 75 Francis Street, Boston, MA 02115.

Received for publication 12 June 1987 and in revised form 8 February 1988.

1. Abbreviations used in this paper: $\beta_{2} \mathrm{M}, \beta_{2}$ microglobulin; CRH, corticotropin-releasing hormone; hCG- $\alpha$, human chorionic gonadotropin alpha subunit; hCRH, human CRH; HPA, hypothalamic-pituitary-adrenal.

J. Clin. Invest.

(c) The American Society for Clinical Investigation, Inc. $0021-9738 / 88 / 07 / 0287 / 06 \$ 2.00$

Volume 82, July 1988, 287-292 human placenta. To determine this directly, we examined hCRH gene expression in human placental tissue. Using genomic CRH probes isolated from man and rat, we detected hCRH mRNA in placenta, and determined that it is similar in size to hypothalamic CRH mRNA. Furthermore, whereas the level of placental hCRH mRNA is very low during the first 30 wk of gestation, it increases over 20 -fold in the 5 wk preceding parturition, in parallel with the rise in placental hCRH peptide content.

\section{Methods}

Tissue preparation. Human placentae from normal pregnancies of gestational ages 7-40 wk were obtained after either therapeutic abortions or Caesarean deliveries. Tissue was cut into $1-\mathrm{cm}$ cubes and frozen immediately in liquid nitrogen. Specimens were prepared separately for RNA extraction and RIA. Tissue was obtained in accordance with the regulations of the Brigham and Women's Hospital Human Subjects Committee.

Preparation of radioactively labeled probes. Two hCRH antisensestrand cRNA probes, hCRH1 and hCRH2, which were complementary to the $5^{\prime}$ or $3^{\prime}$ ends, respectively, of the hCRH gene, were synthesized (Fig. 1) as described previously (10). The template for hCRHI was constructed by subcloning the 377-nucleotide Xmn I-Pst I fragment of the hCRH gene that contains a portion of the $5^{\prime}$ noncoding region (nucleotides $87-463$, reference 11 ), which was obtained from an 8-kb nucleotide-long hCRH genomic clone isolated in our laboratory (10) into the corresponding sites of the plasmid Bluescribe (Stratagene, Inc., La Jolla, CA). Similarly, the template for hCRH2 was constructed by subcloning the 653-nucleotide Sac I-Sph I fragment that contains most of the coding region of the hCRH gene (nucleotides 1,422-2,074) into the corresponding sites of Bluescribe. To generate hCRH1 and hCRH2 cRNA probes, their respective recombinant plasmids were digested with the restriction endonucleases Eco RI (for hCRH1) and Sac I (for hCRH2), and were transcribed with T3 RNA polymerase. A radioactively labeled rat $\mathrm{CRH}$ antisense-strand $\mathrm{CRNA}$ probe, $\mathrm{rCRH} 1$, which is complementary to the 280 nucleotides upstream from the Kpn I site in the $5^{\prime}$ untranslated region of the rat CRH gene (11), was also synthesized after the insertion of the corresponding fragment into the Kpn I/Eco RI site of Bluescribe (Fig. 1). The rat CRH genomic clone was isolated in our laboratory from a rat genomic library (kindly provided by J. Bonner, California Institute Technology) and contains 5 $\mathrm{kb}$ of the $5^{\prime}$ flanking sequence as well as $0.4 \mathrm{~kb}$ of the $3^{\prime}$ flanking sequence (D. Frim, unpublished observations). After digestion with Eco RI, this plasmid was transcribed with T3 RNA polymerase to generate $\mathrm{rCRH} 1$. A radioactively labeled human chorionic gonadotropin alpha subunit (hCG- $\alpha$ ) antisense-strand cRNA probe was synthesized using a template consisting of the full-length hCG- $\alpha$ cDNA (kindly provided by H. Goodman, Harvard University, reference 12) and was subcloned into the Hind III site of Bluescribe. This recombinant plasmid was digested with Bam $\mathrm{HI}$ and was used as a template in the presence of T3 RNA polymerase. The human $\beta_{2}$ microglobulin $\left(\beta_{2} M\right)$ cDNA (13) (kindly provided by J. Seidman, Harvard University) was inserted into the Pst I site of Bluescribe, and the $\beta_{2} M$ antisense cRNA probe was synthesized using T3 RNA polymerase. Radioactively labeled cRNA probes were synthesized as described (14) using 


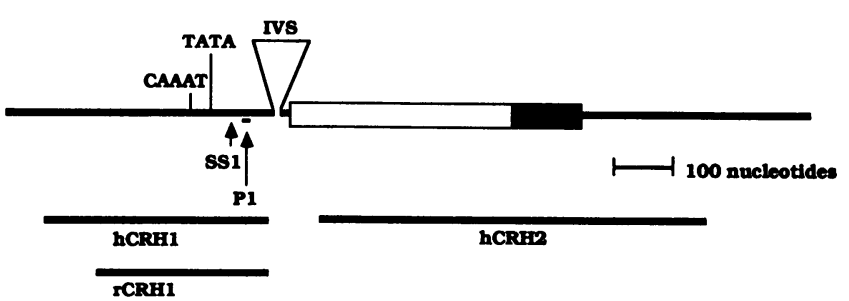

Figure 1. Schematic representation of the locations of cRNA and oligonucleotide probes, complementary to the hCRH gene, used in the analysis of placental hCRH mRNA. Boxed region, DNA sequence encoding prepro-CRH; solid boxed region, DNA sequence encoding CRH peptide; IVS, 800-nucleotide-long intervening sequence (not drawn to scale); $C A A A T$ and $T A T A$, putative promoter elements in the $5^{\prime}$ flanking region of the hCRH gene; $h C R H 1, h C R H 2$, and $r C R H 1$, cRNA probes; $P 1$, synthetic oligonucleotide cDNA probe; SS1, placental CRH mRNA transcriptional initiation site.

$\alpha-\left[{ }^{32} \mathrm{P}\right]$ uridine triphosphate (Amersham Corp., Arlington Heights, IL) except that unincorporated nucleotide was separated from RNA by affinity chromatography on an Elutip column (Schleicher and Schuell, Inc., Keene, $\mathrm{NH}$ ).

A synthetic oligonucleotide, $\mathrm{P} 1$, which was 22 nucleotides in length and synthesized by the phosphite triester method (15), was used in a primer extension analysis of the $5^{\prime}$ end of human placental CRH mRNA (Fig. 1). P1 is complementary to nucleotides $355-376$ of the hCRH gene (16) and was radioactively labeled, using $\gamma-\left[{ }^{32}\right.$ P $]$ ATP (Amersham Corp.) and polynucleotide kinase (Bethesda Research Laboratories, Bethesda, MD), to a specific activity of 3-5 $\times 10^{6} \mathrm{cpm} /$ pmol (17). Unincorporated nucleotide was removed using a Nensorb column (DuPont Co., Wilmington, DE).

RNA filter (Northern) blot hybridization analysis. Total RNA was extracted (18) and 10- $\mu \mathrm{g}$ aliquots (unless otherwise noted) were subjected to Northern blot analysis using $1.4 \%$ agarose gels containing 2.2 $M$ formaldehyde (19). After electrophoresis, RNA was transferred to nitrocellulose (20) and hybridized at $65^{\circ} \mathrm{C}$ to $1 \times 10^{6} \mathrm{cpm}$ of cRNA probe for $18 \mathrm{~h}$. Filters were washed at $65^{\circ} \mathrm{C}$ in two changes of $0.1 \%$ SDS, $15 \mathrm{mM} \mathrm{NaCl}, 1.5 \mathrm{mM}$ sodium citrate, and were then exposed to Kodak XAR5 film at $-80^{\circ} \mathrm{C}$. The amount of $\beta_{2} \mathrm{M}$ mRNA encoding a constitutively expressed component of the class I cell surface antigen (21) was determined by separately probing blots with the $\beta_{2} M$ probe. A semiquantitative assessment of the mRNA detected in the RNA filter hybridization assay was performed by densitometric scanning of autoradiograms of Northern blots using an Ultrascan densitometer (LKB Instruments, Inc., Gaithersburg, MD) (22). The level of hCRH mRNA in each sample was corrected for differences in recovery based on the amount of $\beta_{2} \mathrm{M}$ mRNA detected.

Primer extension analysis of the $5^{\prime}$ end of placental hCRH $m R N A$. Primer extension analysis of the $5^{\prime}$ end of placental hCRH mRNA was performed as previously described (23) except for the following modifications. $5 \mu \mathrm{g}$ of total placental RNA was mixed with 0.1 pmol of radioactively labeled $P 1$ in a $20 \mu \mathrm{l}$ vol and was allowed to hybridize at $45^{\circ} \mathrm{C}$ for $2 \mathrm{~h}$. Reverse transcription was carried out in a $40 \mu \mathrm{l}$ vol at $41^{\circ} \mathrm{C}$ for $1 \mathrm{~h}$. cDNA products were separated by electrophoresis on 0.4-mm-thick $6 \%$ polyacrylamide gels containing $7 \mathrm{M}$ urea, which were exposed to Kodak XAR5 film for $5 \mathrm{~d}$ at room temperature. Dideoxynucleotide DNA sequence analysis (24) was performed with oligonucleotide P1 and a fragment of the hCRH gene (11), which encoded nucleotides 218-417, cloned into the Sma I site of the M13Bluescribe polylinker (Stratagene), using $\alpha-{ }^{35}$ S-dATP (Amersham Corp.) and DNA polymerase (Sequenase; U.S. Biochemical Corp., Cleveland, $\mathrm{OH}$ ). This DNA sequence ladder was subjected to electrophoresis on the same gel as were the reverse transcription cDNA products, so that it could serve as a molecular size standard.

$R I A$ of hCRH peptide in placenta. 0.1-1.0 g of human placental tissue was extracted and lyophilized (25). The lyophilized extract was dissolved in assay buffer immediately before measurement. RIA was performed using a rat/human CRH kit (Peninsula Laboratories, Inc., Belmont, CA) according to the manufacturer's instructions. In this assay, there was $<0.03 \%$ cross-reactivity with the following peptides: oxytocin, ACTH, synthetic ACTH 1-24, $\alpha$-melanocyte-stimulating hormone, $\beta$-endorphin, and $\beta$-hCG. The assay had a sensitivity of 10 $\mathrm{pg} /$ tube and an intraassay coefficient of variation of $15 \%$. All samples were analyzed in a single assay run. hCRH content of tissue samples is expressed as $\mathrm{pg} \mathrm{CRH} / 100 \mathrm{mg}$ tissue.

\section{Results}

RNA filter (Northern) blot hybridization analysis of total RNA isolated from a human placenta of $\mathbf{4 0}$ wk gestation is displayed in Fig. 2. A broad band of RNA $\sim 1,700$ bases in length was detected using the radioactively labeled cRNA probes, hCRH1 and hCRH2, which are complementary to the $5^{\prime}$ and $3^{\prime}$ portions of the hCRH gene, respectively (Figs. 1 and 2 $A$ ). This same 1,700-nucleotide-long mRNA species appeared to comigrate with rat hypothalamic CRH mRNA (Fig. $2 B$ ).

The $5^{\prime}$ transcriptional initiation site of placental hCRH mRNA was determined by primer extension analysis (Fig. 3). Reverse transcription of placental RNA primed with P1 yielded cDNAs 40-43 nucleotides in length. Whether these cDNAs represent a single initiation site associated with variable reverse transcription, or more than one closely associated cap site is not known. No cDNAs were reverse transcribed in the absence of added RNA (Fig. $3 A$ ). Thus, hCRH mRNA, isolated from placentae of 40 -wk gestation, was found to initiate at nucleotide 334 (as well as possibly at nucleotides $335-337$ ) of the hCRH gene (Fig. $3 B$ ). This site is $23-26$ bases downstream from a potential promoter (26) that consists of the sequence CAAAT at nucleotides 271-275 and the sequence TATAAAA at nucleotides 305-311 (Fig. 1).

We next wished to determine whether the content of hCRH mRNA in placenta varied as a function of gestational

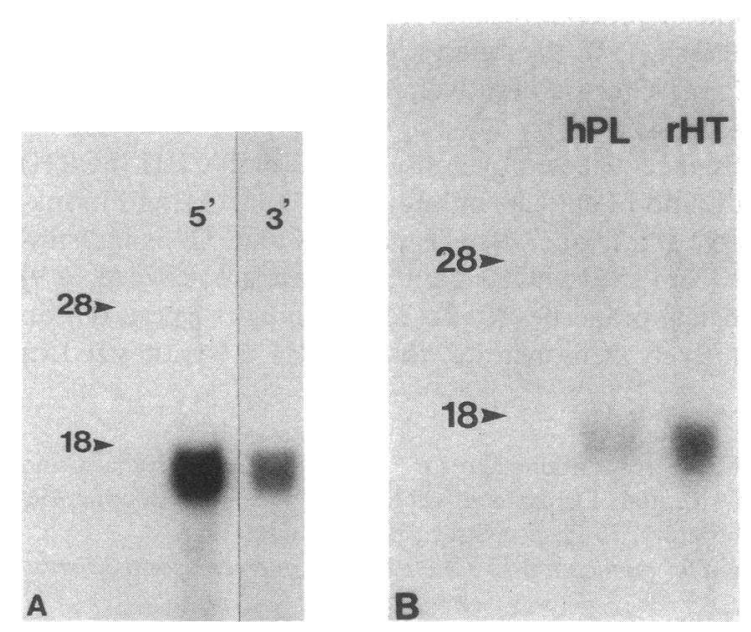

Figure 2. RNA filter hybridization (Northern) blot analysis of placental hCRH mRNA. (A) $10 \mu \mathrm{g}$ of placental RNA was electrophoresed on a $1.4 \%$ agarose gel, transferred to a nitrocellulose membrane, and hybridized to either probe hCRH1 ( $\left.5^{\prime}\right)$ or probe hCRH2 (3'). (B) $0.5 \mu \mathrm{g}$ of placental RNA ( $h P L)$ or $20 \mu \mathrm{g}$ of rat hypothalamic RNA $(r H T)$ were electrophoresed through a $1.4 \%$ agarose gel, transferred to a nitrocellulose membrane, and hybridized to rCRH1. 28 and 18 , positions of migration of $28 \mathrm{~S}$ and $18 \mathrm{~S}$ ribosomal RNA, respectively. 

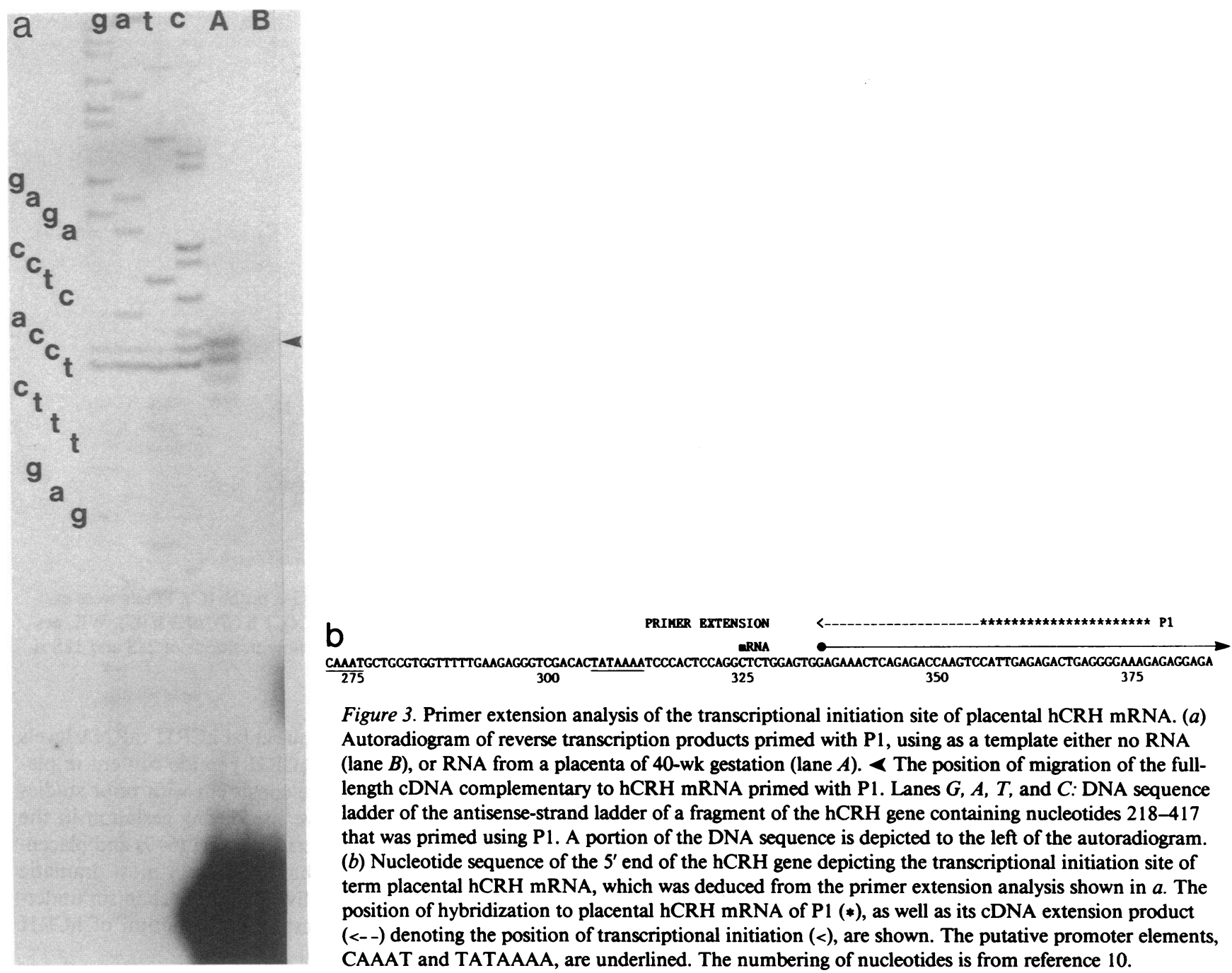

Figure 3. Primer extension analysis of the transcriptional initiation site of placental hCRH mRNA. (a) Autoradiogram of reverse transcription products primed with P1, using as a template either no RNA (lane $B$ ), or RNA from a placenta of 40 -wk gestation (lane $A$ ). $<$ The position of migration of the fulllength cDNA complementary to hCRH mRNA primed with P1. Lanes $G, A, T$, and $C$ : DNA sequence ladder of the antisense-strand ladder of a fragment of the hCRH gene containing nucleotides 218-417 that was primed using P1. A portion of the DNA sequence is depicted to the left of the autoradiogram. (b) Nucleotide sequence of the $5^{\prime}$ end of the hCRH gene depicting the transcriptional initiation site of term placental hCRH mRNA, which was deduced from the primer extension analysis shown in $a$. The position of hybridization to placental hCRH mRNA of P1 (*), as well as its CDNA extension product (<--) denoting the position of transcriptional initiation (<), are shown. The putative promoter elements, CAAAT and TATAAAA, are underlined. The numbering of nucleotides is from reference 10.

age. Total RNA was extracted from placentae whose gestational ages varied between 7 and 40 wk. Northern blot analysis of these RNAs, which was performed using the cRNA probe, hCRH1, is displayed in Fig. $4 \mathrm{~A}$. A low but detectable amount of hCRH mRNA was present in placentae of 7-19 wk gestation. There was a marked increase in the amount of hCRH mRNA in placental samples of $35-40$ wk gestation. Similar amounts of the constitutively expressed 1-kb-long $\beta_{2} \mathrm{M}$ mRNA were detected in placental mRNA preparations of all gestational ages (Fig. $4 \mathrm{~B}$ ). Selected placental RNA preparations were further analyzed for the expression of hCG- $\alpha$ mRNA (Fig. $4 C$ ). In contrast to the findings for hCRH mRNA, the 600 -base-long hCG- $\alpha$ mRNA was expressed to the greatest extent in RNA that was isolated from first trimester placentae, and was reduced in RNA samples obtained from placentae of later gestational ages.

A semiquantitative assessment of the amount of hCRH mRNA and peptide present in placentae of different gestational ages is displayed in Fig. 5. Compared with first trimester samples, there was more than a 20-fold increase in both hCRH mRNA and peptide during the final 5 wk of gestation. Low but detectable levels of hCRH mRNA were present in first and second trimester samples, but hCRH peptide could be detected by RIA only in second and third trimester samples.

\section{Discussion}

Our results demonstrate that authentic hCRH mRNA is present in human placenta, which strongly implies that the hCRH gene is transcribed in this tissue. Since the initial finding of a CRH-like factor in extracts of human placenta (5), several studies have addressed the structural characterization and biosynthetic source of this factor. This CRH-like substance reacts with anti-CRH antisera in a manner indistinguishable from that of native hCRH (6-9). It is also equipotent when compared with native hCRH in bioassay systems $(5,9)$, and it comigrates with native $\mathrm{CRH}$ during gel exclusion chromatography $(6,7,9)$. Moreover, there is a gradient in immunoreactive plasma hCRH levels across the placenta $(7,9)$. Taken together, these data suggest that a form of hCRH that is indistinguishable from hypothalamic $\mathrm{CRH}$ is synthesized in human placenta. We now offer compelling evidence in support of this suggestion by the demonstration of both hCRH mRNA and the parallel increase in hCRH mRNA and peptide in human placenta during gestation.

Our results suggest that the structure of placental hCRH mRNA is very similar to that predicted for hypothalamic hCRH mRNA (16). The detection of placental hCRH mRNA by both 5'- and 3'-directed hCRH genomic probes suggests that 

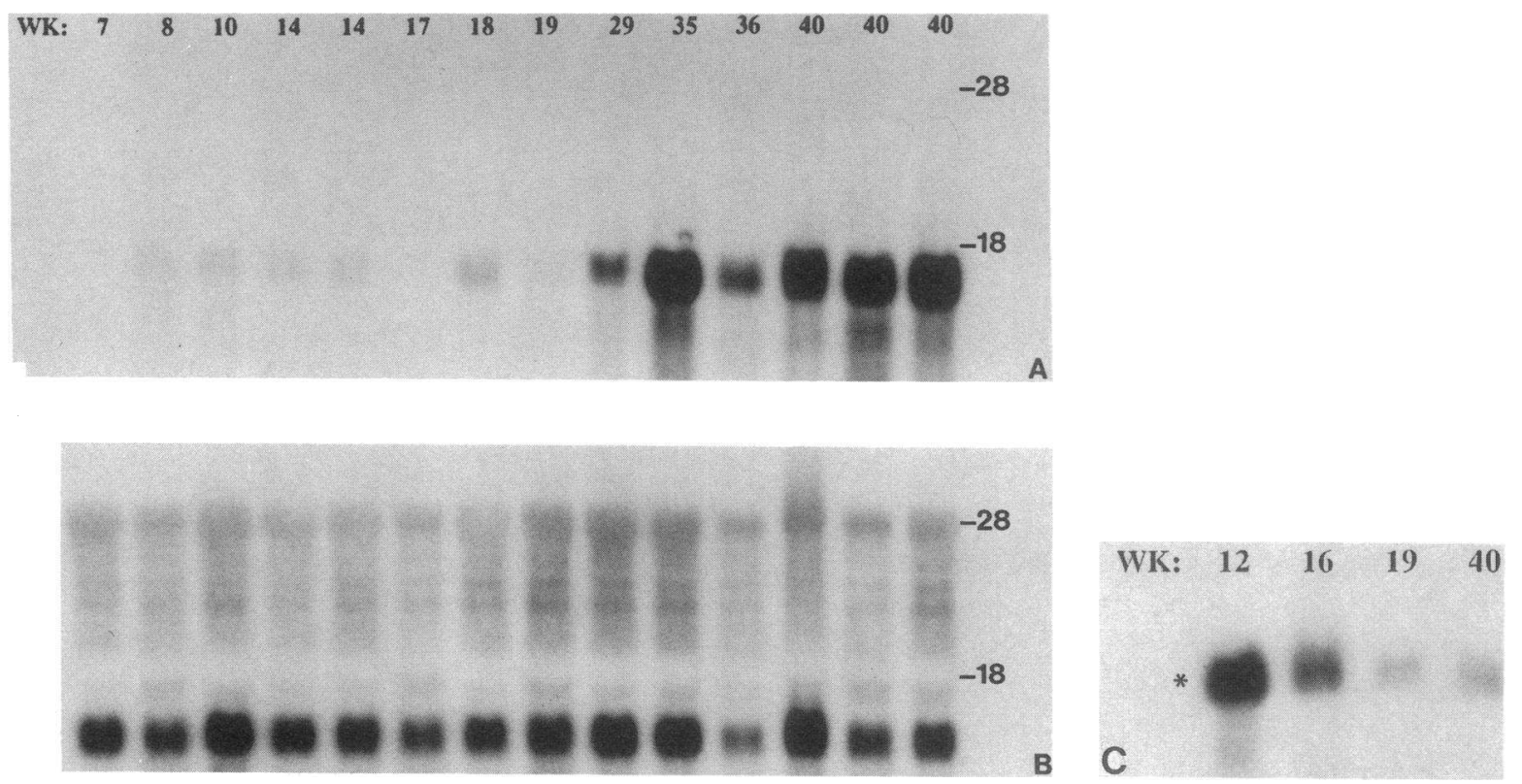

Figure 4. RNA filter hybridization (Northern) blot analysis of total RNA, $5 \mu \mathrm{g} /$ lane, isolated from placentae of gestational ages varying between 7 and $40 \mathrm{wk}$. The same filter was probed first with the hCRH1 probe $(A)$ followed $14 \mathrm{~d}$ later by the $\beta_{2} \mathrm{M}$ probe $(B)$. A sepa-

both 5'- and 3'-related CRH genomic sequences are contained within the species of hCRH mRNA that was detected in placenta. Furthermore, our finding that the site of transcriptional initiation of hCRH mRNA, which was isolated from term placenta is at nucleotide 334 of the hCRH gene, is in agreement with Shibahara et al.'s (16) prediction of the initiation site for hypothalamic hCRH mRNA, which they made based upon the location of a consensus promoter element in the hCRH gene 23 nucleotides upstream from this site (16).

hCRH mRNA is detected in placenta from 7 to $40 \mathrm{wk}$ of gestation, and increases more than 20-fold during the last 5 wk
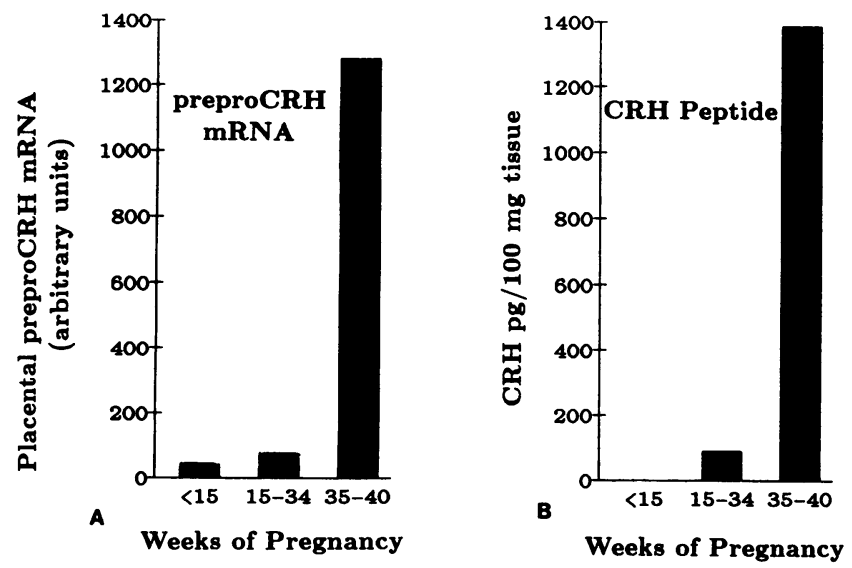

Figure 5. Changes in placental hCRH mRNA $(A)$ and hCRH peptide $(B)$ during gestation. $(A)$ Autoradiograms displayed in Fig. 4, $A$ and $B$ were scanned densitometrically, and the corrected areas under the curve representing hCRH mRNA levels were plotted in arbitrary units. (B) RIA of placental hCRH peptide extracted from the same placentae from which the RNA analyzed in Fig. $4, A$ and $B$ was isolated. rate filter was hybridized to the hCG- $\alpha$ probe $(C)$. Filters were exposed to x-ray film for either $24 \mathrm{~h}(A), 1 \mathrm{~h}(B)$, or $3 \mathrm{~h}(C)$. WK, gestational age in weeks. 28 and 18 denote positions of $28 \mathrm{~S}$ and $18 \mathrm{~S}$ ribosomal RNA, respectively.

of pregnancy. This increase in placental hCRH mRNA levels coincides with the increase in hCRH peptide content in placental tissue. These findings are consistent with prior studies that demonstrated a progressive rise during gestation in the levels of hCRH peptide in maternal plasma (6-9) and placental tissue (9). These increases have also been most dramatic during the final 5 wk before delivery. The mechanism underlying the marked degree of gestational variation of hCRH mRNA in placenta is unknown.

In addition to hCRH, hCG, and chorionic somatomammotropin, several other peptide hormones are expressed in the human placenta (27). These include ACTH (28), thyrotropinreleasing hormone (29), gonadotropin-releasing hormone (30), and somatostatin (31). The mRNAs that encode some of these neuropeptides have also been detected in placenta $(32,33)$.

The role of placental CRH in maternal-placental-fetal physiology is not known. Since placental CRH has been shown to be secreted into both the maternal (6-9) and fetal (7-9) circulations, it could conceivably function to influence the HPA axis of either mother or fetus. In fact, the dramatic rise in human fetal cortisol at 34-35 wk of gestation (34), at a time when placental CRH is also increasing rapidly, is compatible with a role for placental CRH in the regulation of the fetal HPA axis. In this context, hCRH might play a role in parturition, since it has been demonstrated that this event is influenced by fetal glucocorticoid levels in at least some mammalian species (35). Alternatively, in light of the presence of proopiomelanocortin mRNA (32) and ACTH (28) in human placenta, it is possible that placental hCRH may act in a paracrine fashion to regulate placental proopiomelanocortin expression (36).

There appears to be differential tissue-specific regulation of the hCRH gene in placenta and hypothalamus. In the latter, hCRH mRNA and peptide are expressed at low levels and are negatively regulated by glucocorticoid $(3,4)$. In contrast, pla- 
cental hCRH mRNA and peptide increase dramatically during gestation. Furthermore, levels of hCRH in placenta are not negatively regulated by glucocorticoid. In one study (37), pregnant women treated with large doses of the potent glucocorticoid, betamethasone, had no reduction in plasma CRH levels, despite a reduction in plasma ACTH and in cortisol. In a second study (38), $10^{-6} \mathrm{M}$ dexamethasone failed to suppress the release of hCRH from perifused placental fragments. CRH is encoded by a single locus on the long arm of chromosome 8 (39). Thus, the differential regulation of the hCRH gene in placenta and hypothalamus is most likely due to tissue-specific differences in either transacting cellular components, cisacting DNA sequences within the hCRH gene, or to both factors. Elucidation of these differences will aid in the further understanding of the mechanisms of $\mathrm{CRH}$ gene regulation.

\section{Acknowledgments}

We thank R. Osathanondh and the nurses on the labor and delivery floor of the Brigham and Women's Hospital for obtaining placental specimens, $H$. Goodman for the gift of the hCG- $\alpha$ cDNA clone, J. Seidman for the $\beta_{2} M$ cDNA clone, G. Gryan for the synthesis of synthetic oligonucleotides, L. D'Angio for technical assistance, and $M$. Jacobs for excellent secretarial assistance.

D. Frim was supported in part by Public Health Service grant 2T 32GM07753-07, and B. Robinson by grants from the Medical Foundation, the University of Sydney, and the Royal Australasian College of Physicians.

\section{References}

1. Vale, W., J. Spiess, C. Rivier, and J. Rivier. 1981. Characterization of a 41-residue ovine hypothalamic peptide that stimulates secretion of corticotropin and $\beta$-endorphin. Science (Wash. DC). 213:1394-1397.

2. Affolter, H.-U., and T. Reisine. 1985. Corticotropin releasing factor increases proopiomelanocortin messenger RNA in mouse anterior pituitary tumor cells. J. Biol. Chem. 260:15477-15481.

3. Sawchenko, P. E., L. W. Swanson, and W. W. Vale. 1984. Coexpression of corticotropin-releasing factor and vasopressin immunoreactivity in parvocellular neurosecretory neurons of the adrenalectomized rat. Proc. Natl. Acad. Sci. USA. 81:1883-1887.

4. Jingami, J., S. Matsukura, S. Numa, and H. Imura. 1985. Effects of adrenalectomy and dexamethasone administration on the level of prepro-corticotropin-releasing factor messenger ribonucleic acid (mRNA) in the hypothalamus and adrenocorticotropin/ $\beta$-lipotropin precursor mRNA in the pituitary in rats. Endocrinology. 117:13141320.

5. Shibasaki, T., E. Odagiri, K. Shizume, and N. Ling. 1982. Corticotropin-releasing factor-like activity in human placental extracts. $J$. Clin. Endocrinol. \& Metab. 55:384-386.

6. Sasaki, A., A. S. Liotta, M. M. Luckey, A. N. Margioris, T. Suda, and D. T. Krieger. 1984. Immunoreactive corticotropin-releasing factor is present in human maternal plasma during the third trimester of pregnancy. J. Clin. Endocrinol. \& Metab. 59:812-814.

7. Goland, R. S., S. L. Wardlaw, R. I. Stark, L. S. Brown, Jr., and A. G. Frantz. 1986. High levels of corticotropin-releasing hormone immunoactivity in maternal and fetal plasma during pregnancy. $J$. Clin. Endocrinol. \& Metab. 63:1199-1203.

8. Campbell, E. A., E. A. Linton, D. A. Wolfe, P. R. Scraggs, M. T. Jones, and P. J. Lowry. 1987. Plasma corticotropin-releasing hormone concentrations during pregnancy and parturition. J. Clin. Endocrinol. \& Metab. 64:1054-1059.

9. Sasaki, A., O. Shinkawa, A. N. Margioris, A. S. Liotta, S. Sato, O. Murakami, M. Go, Y. Shimuzu, K. Hanew, and K. Yoshinaga. 1987.
Immunoreactive corticotropin-releasing hormone in human plasma during pregnancy, labor, and delivery. J. Clin. Endocrinol. \& Metab. 64:224-229.

10. Adler, G. K., C. M. Smas, and J. A. Majzoub. 1988. Expression and dexamethasone regulation of the human corticotropin releasing hormone gene in a mouse anterior pituitary cell line. J. Biol. Chem. 263:5846-5852.

11. Thompson, R. C., A. F. Seasholtz, and E. Herbert. 1987. Rat corticotropin-releasing hormone gene: sequence and tissue-specific expression. Mol. Endocrinol. 1:363-370.

12. Fiddes, J. C., and H. M. Goodman. 1979. Isolation, cloning, and sequence analysis of the cDNA for the alpha-subunit of human chorionic gonadotropin. Nature (Lond.). 281:351-356.

13. Suggs, S. V., R. B. Wallace, T. Hirose, E. H. Kawashima, and K. Itakura. 1981. Use of synthetic oligonucleotides as hybridization probes: isolation of cloned cDNA sequences for human beta 2-microglobulin. Proc. Natl. Acad. Sci. USA. 78:6613-6617.

14. Melton, J., P. A. Krieg, M. R. Rebagliati, T. Maniatis, K. Zinn, and M. R. Green. 1984. Efficient in vitro synthesis of biologically active RNA and RNA hybridization probes from plasmids containing a bacteriophage SP6 promoter. Nucleic Acids Res. 12:7035-7065.

15. Caruthers, M. H., S. L. Beaucage, J. Efcavitch, E. Fisher, M. Matteucci, and Y. Stabinsky. 1980. New chemical methods for synthesizing polynucleotides. Nucleic Acids Symp. Ser. 1:215-223.

16. Shibahara, S., Y. Morimoto, Y. Furutani, M. Notake, H. Takahashi, S. Shimizu, S. Horikawa, and S. Numa. 1983. Isolation and sequence analysis of the human corticotropin-releasing factor precursor gene. EMBO (Eur. Mol. Biol. Organ.) J. 2:775-779.

17. Maxam, A. M., and W. Gilbert, 1980. Sequencing end-labeled DNA with base-specific chemical cleavages. Methods Enzymol. 65:499-560.

18. Chirgwin, J. M., A. E. Przybyla, R. J. MacDonald, and W. J. Rutter. 1979. Isolation of biologically active ribonucleic acid from sources enriched in ribonuclease. Biochemistry. 18:5294-5299.

19. Lehrach, H., D. Diamond, J. M. Wozney, and H. Boedtker. 1977. RNA molecular weight determinations by gel electrophoresis under denaturing conditions, a critical reexamination. Biochemistry. 16:4743-4751.

20. Thomas, P. S. 1980. Hybridization of denatured RNA and small DNA fragments transferred to nitrocellulose. Proc. Natl. Acad. Sci. USA. 77:5201-5205.

21. Parnes, J. R., Robinson, R. R., and Seidman, J. G. 1983. Multiple mRNA species with distinct $3^{\prime}$ termini are transcribed from the beta 2-microglobulin gene. Nature (Lond.). 302:449-452.

22. Majzoub, J. A., E. Carrazana, J. S. Shulman, K. J. Baker, and R. L. Emanuel. 1987. Defective regulation of vasopressin gene expression in the Brattleboro rat. Am. J. Physiol. 252:E637-E642.

23. Majzoub, J. A., A. Rich, J. van Boom, and J. F. Habener. 1983. Vasopressin and oxytocin mRNA regulation in the rat assessed by hybridization with synthetic oligonucleotides. J. Biol. Chem. 258:14061-14064.

24. Sanger, F., S. Nicklen, and A. Coulson. 1977. DNA sequencing with chain-terminating inhibitors. Proc. Natl. Acad. Sci. USA. 74:5463-5467.

25. Suda, T., N. Tomori, F. Tozawa, T. Mouri, H. Demura, and K. Shizume. 1984. Distribution and characterization of immunoreactive corticotropin-releasing factor in human tissues. J. Clin. Endocrinol. \& Metab. 59:861-866.

26. Chambon, P., A. Dierich, M.-P. Gaub, S. Jakowlev, J. Jongstra, A. Krust, J.-P. LePennec, P. Oudet, and T. Reudelhuber. 1984. Promoter elements of genes coding for proteins and modulation of transcription by estrogens and progesterone. Recent Prog. Horm. Res. 40:1-42.

27. Fisher, D. A. 1986. The unique endocrine milieu of the fetus. $J$. Clin. Invest. 78:603-611.

28. Liotta, A., R. Osathanondh, K. J. Ryan, and D. T. Krieger. 1977. Presence of corticotropin in human placenta: demonstration of in vitro synthesis. Endocrinology. 101:1552-1558. 
29. Shambaugh, G., M. Kubek, and J. Wilber. 1979. Thyrotropinreleasing hormone activity in the human placenta. J. Clin. Endocrinol. \& Metab. 48:483-486.

30. Siler-Khodr, T. M., and G. S. Khodr. 1983. Gonadotropin releasing hormone $(\mathrm{GnRH})$ in the placenta. In The Role of Peptides and Proteins in Control of Reproduction. S. M. McCann, editor. Elsevier/North Holland, New York. 317.

31. Watkins, W. B., and S. S. C. Yen. 1980. Somatostatin in the cytotrophoblast of the immature human placenta: localization by immunoperoxidase cytochemistry. J. Clin. Endocrinol. \& Metab. 5:969971.

32. Chen, C. C., C. Chang, D. T. Krieger, and C. W. Bardin. 1986. Expression and regulation of proopiomelanocortin-like gene in the ovary and placenta: comparison with the testis. Endocrinology. 118:2382-2389.

33. Seeburg, P. H., and J. Adelman. 1984. Characterization of cDNA for luteinizing hormone releasing hormone. Nature (Lond.). 311:666-668.
34. Fencl, M. M., and D. Tulchinsky. 1975. Total cortisol in amniotic fluid and fetal lung maturation. N. Engl. J. Med. 292:133-136.

35. Liggins, G. C. 1976. Adrenocortical-related maturational events in the fetus. Am. J. Obstet. Gynecol. 126:931-941.

36. Petraglia, F., P. E. Sawchenko, J. Rivier, and W. Vale. 1987. Evidence for local stimulation of ACTH secretion by corticotropin-releasing factor in human placenta. Nature (Lond.). 328:717-719.

37. Goland, R. S., S. L. Wardlaw, P. J. Tropper, H. C. Fox, and A. G. Frantz. 1986. High levels of maternal plasma corticotropin releasing factor during pregnancy are not suppressed by glucocorticoid. Clin. Res. 34:425a. (Abstr.)

38. Margioris, A., M. Grino, and G. Chrousos. 1987. Perifused human placental fragments release immunoreactive corticotropin releasing factor. Program Endocrine Soc. 69th Annu. Meeting. 246. (Abstr.)

39. Arbiser, J. L., C. C. Morton, G. A. P. Bruns, and J. A. Majzoub. 1988. Human corticotropin releasing hormone gene is located on the long arm of chromosome 8. Cytogenet. Cell Genet. 47:113-116. 